\title{
Employment Scenario and Labour Migration in Marine Fisheries
}

\author{
R. SATHIADHAS* and SANGEETHA K. \\ PRATHAP Socio Economic Evaluation and Technology \\ Transfer Division Central Marine Fisheries Research Institute \\ Cochin, Kerala, India. PIN: 682018
}

\begin{abstract}
Employment status and opportunities in marine fisheries sector increased over the years inspite of growing mechanization and incessant replacement of labour intensive fishing technologies. Fish, being a highly perishable product, needs the services of several people for its fast movement from catching point to consuming point without deteriorating its quality. It provides employment not only to fisherfolk in fishing villages, but also to those hailing from adjoining as well as interior regions. The present study attempts to assess the manpower employed in active fishing as well as in secondary and tertiary sectors both from coastal villages and other regions. Macro level employment status has been worked out based on the well established assumption that every $5 \mathrm{~kg}$ of marine fish produced provides employment to one person in the harvesting and another 1.2 persons in the post harvest sector (Sathiadhas et al. 1997). The study indicates that about 12.5 lakh people are involved in active fishing in India while the postharvest sector including export and domestic marketing employs about 15 lakh and in tertiary sector there are around 2 lakh people. Among these, 71 percent of active fishers, 50 percent of secondary sector workers and 42 percent in the tertiary sector are inhabitants of coastal fishing villages. In secondary sector, around 30 percent are women workers of which 81 percent are residents of fishing villages in the coastal belt. There is ample scope of development of employment potential of secondary and tertiary sectors in view of globalization of economy. An additional export of almost 1 lakh tonnes of value added products in our marine exports could easily corner about Rs. 1500 cores of forex earnings and generate regular employment opportunity for about 35,000 fisherfolk.

Technological changes in fishing coupled with the widespread use of electronic gadgets like mobile phones and GPS have promoted migration of fisherfolk in search of better catch and earnings. A case study of socio economic dimensions of migrant fisher folk who are natives of Colachel, Thoothoor, and Vallavilai regions of Kanyakumari District of Tamil Nadu was carried out for which primary data were collected by the help of pre-structured schedules. Migratory fishing is having definite implications upon the social and economic milieu of migrants as well as on the migrants' families who are left back at their native place. Factors inducing migration among these fisherfolk include high demand for shark in the international market coupled with its earning potential, accessibility to landing points, and berthing facilities and better price
\end{abstract}

\footnotetext{
* Corresponding Author.

Email : rsathiadhas_seettd@yahoo.com
} 
realization. Constraints faced by in-country migrants include fluctuating returns resulting in insufficient income and indebtedness, frequent clashes with locals of landing center in other states, exploitation of migrant fishing units in other states, forced sales, delay in payment of sale proceeds, missing of fishing boats/fishermen and ergonomic problems due to long fishing trips without adequate facilities. Foreign migrants face problems like detention due to crossing maritime borders, withholding of passports and other documents, ill treatment from the sponsors and exploitation due to ignorance of fishermen.

\section{Introduction}

Fisheries sector has been faring high in terms of its forex earning potential and employability of vast majority of coastal community in the primary, secondary, and tertiary sectors associated with fishing. However, the plight of marine fisherfolk amplified by inequitable distribution of earnings leading to indebtedness and marginalization is a much debated issue for the planners and policy makers. Improvements in technology has led to unbridled capital investment in this sector and has attracted more and more people from the adjacent coastal transects who necessarily do not belong to the fishing community. Seafood exports from India is exploring new heights with increasing opportunities for value addition and branding of products. This has led to mushrooming of export units employing large number of skilled and unskilled workers. Further over the years, there is increase in the coastal fisher population inducing more and more people in fishing and allied activities. Disguised unemployment is rampant in all sectors since earnings from marine fisheries are not proportionate to the increase in stakeholders. This has instigated labour migration induced by the earning potential in the distant waters coupled with limited resources in their vicinity. The study attempts to estimate the trend in labour force employed in active fishing in marine fisheries over the years, the sectoral distribution of labour force, and extent of migration. This paper also analyses the case of Tamil fishermen of Kanyakumari coast who relocate to different places for fishing, the factors that induce migration and problems associated with it.

\section{Materials and Methods}

The study has been done widely depending on primary and secondary sources of information. The data about labour requirement for each type of craft-gear combinations in the primary sector and the number of persons employed in secondary sector activities were collected from the 20 sample units at selected centres. Detailed household survey to assess the socio economic implications of migration were conducted during 2006 in villages of Thoothoor, Colachel, and Vallavilai along Kanyakumari coast. Secondary sources of information include catch figures and marine fisheries census reports of CMFRI for various years. 


\section{Results and Discussion}

\section{Coastal population dynamics and employment in active fishing}

The marine fisheries census of CMFRI has estimated coastal population and manpower employed in active fishing and related sectors from time to time. The active fishers in coastal villages in marine fisheries have been increasing over the years at a compound growth rate of 3.13 percent (Table 1) almost in consonance with population growth of 3 percent. Marine fisheries is recognized as a sunrise sector and the prospects

Table 1. Growth of active fishermen in coastal fishing villages over years (1961-62 to 2005)

\begin{tabular}{|c|c|c|c|c|c|c|}
\hline State & $1961-62$ & $1973-77$ & 1980 & 2005 & $\begin{array}{l}\text { Compound } \\
\text { annual growth } \\
\text { rate of active } \\
\text { fishers } \\
(\%)\end{array}$ & $\begin{array}{l}\text { Compound } \\
\text { annual } \\
\text { population } \\
\text { growth rate } \\
\text { (\%) }\end{array}$ \\
\hline West Bengal & 9434 & 15076 & $\begin{array}{l}19756 \\
(24)\end{array}$ & $\begin{array}{c}70750 \\
(26)\end{array}$ & $8.88 * *$ & $4.8 * *$ \\
\hline Orissa & (26) & (25) & $\begin{array}{l}30724 \\
(26)\end{array}$ & $\begin{array}{c}121282 \\
(27)\end{array}$ & 9.59 & 5.53 \\
\hline Andhra Pradesh & $\begin{array}{l}4 \% / 00 \\
(35)\end{array}$ & $\begin{array}{l}645 y^{\prime} 2 \\
(27)\end{array}$ & $\begin{array}{l}83903 \\
(26)\end{array}$ & $\begin{array}{c}138614 \\
(27)\end{array}$ & 2.45 & 3.03 \\
\hline Tamil Nadu & $\begin{array}{l}56586 \\
(26)\end{array}$ & $\begin{array}{l}68317 \\
(24)\end{array}$ & $\begin{array}{l}96500 \\
(24)\end{array}$ & $\begin{array}{c}206908 \\
(26)\end{array}$ & $3.76^{*}$ & $3.42 *$ \\
\hline Pondichery & & $\begin{array}{l}3785 \\
(23)\end{array}$ & $\begin{array}{l}5512 \\
(22)\end{array}$ & $\begin{array}{c}10341 \\
(24)\end{array}$ & $3.41 *$ & $3.26 *$ \\
\hline Kerala & $\begin{array}{l}74241 \\
(22)\end{array}$ & $\begin{array}{l}80898 \\
(21)\end{array}$ & $\begin{array}{l}131101 \\
(20)\end{array}$ & $\begin{array}{c}140222 \\
(23)\end{array}$ & 1.46 & 1.35 \\
\hline Karnataka & $\begin{array}{l}8963 \\
(17)\end{array}$ & $\begin{array}{l}21740 \\
(22)\end{array}$ & $\begin{array}{l}25005 \\
(22)\end{array}$ & $\begin{array}{c}37632 \\
(22)\end{array}$ & 3.31 & 2.76 \\
\hline Maharashtra & $\begin{array}{l}20698 \\
(20)\end{array}$ & $\begin{array}{l}41539 \\
(21)\end{array}$ & $\begin{array}{l}72074 \\
(23)\end{array}$ & & 2.88 & 2.59 \\
\hline Gujarat & $\begin{array}{l}11732 \\
(14)\end{array}$ & $\begin{array}{l}22518 \\
(18)\end{array}$ & $\begin{array}{l}83322 \\
(26)\end{array}$ & $\begin{array}{c}36527 \\
(24)\end{array}$ & 4.56 & 3.16 \\
\hline Goa & NA & 4067 & $\begin{array}{l}8871 \\
(22)\end{array}$ & $\begin{array}{l}2515 \\
(24)\end{array}$ & $2.44 \#$ & $3.35 \#$ \\
\hline Daman \& Diu & NA & & & $\begin{array}{c}5868 \\
(20) \\
\end{array}$ & & \\
\hline Total & $\begin{array}{l}229354 \\
(24)\end{array}$ & $\begin{array}{l}322532 \\
(22)\end{array}$ & $\begin{array}{l}437899 \\
(23)\end{array}$ & $\begin{array}{l}889528 \\
(25)\end{array}$ & 3.13 & 3 \\
\hline
\end{tabular}

** Growth rate of last 15 years

\# Combined growth rate of Goa, Daman and Diu

* Growth rate of last 30 years 
of foreign exchange earnings and employability is attracting more and more people into active fishing and allied sectors. Although there was a general increase in active fishers in all the maritime states, high variation was observed in relation to increase in total population. Active fishers increased more than proportionate to the growth in population in the states of West Bengal, Orissa, Karnataka, and Gujarat. Conversely, there was lesser growth rate of active fishers compared to population growth in Andhra Pradesh and UT of Daman and Diu. However, there was not much change in the proportion of active fishers in the total population as the overall share of active fishers increased from 24 percent in 1961-62 to 25 percent in 2005).

\section{Sectoral distribution of active fishers}

Human resource utilization in marine fisheries covers not only the coastal fisherfolk but also the adjacent and some times distant residents also. It was estimated that roughly 12.5 lakh people are involved in active fishing while 15 lakh involve in secondary and about 2 lakh in tertiary sectors. On an average, $5 \mathrm{~kg}$ of marine fish produced gives employment to one in harvesting and 1.2 persons in post harvest sector. The sectoral distribution of employment pattern of active fishers over the years is presented in Table 2.

There is a clear shift of employment pattern towards mechanised and motorized sectors. The active fishers in the mechanised segment increased from 24 percent in 1980-81 to 35 percent in 2004-05 and motorized segment from 17 percent in 1997-98 to 32 percent in 2004-05. The share of active fishers in the non-mechanised segment decreased from 75 percent in 1980-81 to 34 percent in 2004-05.

Table 2. Sectoral distribution and growth of active fishermen in India

\begin{tabular}{lcccc}
\hline Active fishermen in & $1980-81$ & $1997-98$ & $2003-04$ & $2004-05$ \\
\hline Mechanised sector & $114000(24)$ & $200000(20)$ & $412596(34)$ & $430931(35)$ \\
Motorised sector & - & $170000(17)$ & $442581(36)$ & $401577(32)$ \\
Non Mechanised sector & $348000(75)$ & $650000(64)$ & $365360(30)$ & $415312(34)$ \\
\hline Total & 462000 & 1020000 & 1220577 & 1247820 \\
\hline
\end{tabular}

Source: Various marine fisheries census of CMFRI

While there is considerable sectoral shift by active fishers in marine fisheries, the extent of their dependence on fishing activities remain almost stable with increase in population (Table 3). The total active fishers in marine fisheries and full time fishers doubled during the past 15 years. The increase in part time fishers were more than other categories (137 percent) with 13 percent of the total active fishers engaged in part time fishing compared to the earlier 11 percent. 
Table 3. Change in involvement in active fishing over the years

\begin{tabular}{lcccc}
\hline Year & Full time & Part time & Occasional & Total \\
\hline 1980 & $357703(82)$ & $49654(11)$ & $30542(7)$ & $437899(100)$ \\
2005 & $717999(81)$ & $117628(13)$ & $53901(6)$ & $889528(100)$ \\
$\begin{array}{l}\text { Growth } \\
\text { (percent) }\end{array}$ & 101 & 137 & 76 & 103 \\
\hline
\end{tabular}

\section{Current employment scenario of marine fisheries in India}

In India, marine fisheries sector employs around two million people of which 12.47 lakh people are in active fishing, 14.97 lakh in secondary sector avocations and two lakhs in tertiary sector. Out of the total employed, 59 percent of them hail from the coastal fishing villages alone. It is observed that most of the sea faring fishers also live in the nearby coastal villages. Seventy one percent of those employed in primary sector reside in coastal fishing villages (Table 4). Similarly, 51 percent of secondary sector workers and 42 percent of tertiary sector workers are from the fishing villages. The export orientation of marine fisheries sector has led to mushrooming of seafood export units doing varied activities like peeling, curing, preprocessing, processing and packing. These units have high employment potential and employ women in large numbers. Women in nonfishing areas also are attracted to such jobs that have resulted in overcrowding effect leading to low wage rate. In secondary sector, around 30 percent are women workers of which 81 percent are residents of fishing villages in the coastal belt. The tertiary sector undertakes fishery allied activities in which nonfishermen dominate.

Table 4. Employment pattern in marine fisheries and coastal fishing villages (2005)

\begin{tabular}{lccc}
\hline & \multicolumn{2}{c}{ Marine fisheries sector } & \multicolumn{2}{c}{ Coastal fishing villages } \\
\cline { 2 - 4 } & $\begin{array}{c}\text { Total number of people } \\
\text { employed(lakh) }\end{array}$ & $\begin{array}{c}\text { Number of people } \\
\text { employed (lakh) }\end{array}$ & $\begin{array}{c}\text { percentage of total } \\
\text { employment }\end{array}$ \\
\hline Primary & 12.47 & 8.89 & 71 \\
Secondary & 14.97 & 7.56 & 51 \\
Women in & 4.49 & 3.65 & 81 \\
secondary sector & 2.00 & 0.83 & 42 \\
Tertiary & 29.44 & 17.28 & 59 \\
\hline Total & & & \\
\hline
\end{tabular}


The state wise break up of the total people employed in primary and secondary sector in marine fisheries is given in Table 5. Fisherfolk from the coastal fishing villages form a part of the total labour employed in marine fisheries. The primary sector workforce in marine fisheries was estimated on the basis of average employment pattern in the fishing crafts in the respective states. More than 90 percent of people from coastal villages are involved in active fishing in the states of Orissa, Andhra Pradesh, and Tamil Nadu and rest comes from adjacent villages and even from other states. In states like Karnataka, Goa, Maharashtra, and Gujarat less than half of the active fishermen are from fishing villages.

Table 5. State wise employment pattern in marine fisheries and coastal fishing villages (2005)

\begin{tabular}{|c|c|c|c|c|c|c|}
\hline \multirow[b]{3}{*}{ State } & \multicolumn{2}{|c|}{ (A) } & \multicolumn{2}{|c|}{ (B) } & \multirow{2}{*}{\multicolumn{2}{|c|}{$\begin{array}{l}\text { percent of } \\
\text { (B) to (A) }\end{array}$}} \\
\hline & \multicolumn{2}{|c|}{$\begin{array}{l}\text { Total employed in } \\
\text { marine fisheries }\end{array}$} & \multicolumn{2}{|c|}{$\begin{array}{l}\text { Inhabitants of coastal } \\
\text { fishing villages }\end{array}$} & & \\
\hline & Primary & Secondary & Primary & Secondary & Primary & Secondary \\
\hline West Bengal & $1,12,144$ & $1,34,573$ & 70,750 & 57,741 & 63 & 43 \\
\hline Orissa & $1,34,669$ & $1,61,603$ & $1,21,282$ & $1,52,534$ & 90 & 94 \\
\hline Andhra Pradesh & $1,47,289$ & 176,747 & $1,38,614$ & $1,52,892$ & 94 & 87 \\
\hline Tamil Nadu & $2,25,102$ & $2,70,122$ & $2,06,908$ & $1,04,509$ & 92 & 39 \\
\hline Pondichery & 18,461 & 22,153 & 10,341 & 10,095 & 56 & 46 \\
\hline Kerala & $1,94,816$ & $2,33,779$ & $1,40,222$ & 71,074 & 72 & 30 \\
\hline Karnataka & $1,05,721$ & $1,26,865$ & 37,632 & 45,699 & 36 & 36 \\
\hline Goa & 16,237 & 19,484 & 2,515 & 3,382 & 15 & 17 \\
\hline Maharashtra & $1,36,628$ & $1,63,954$ & 72,074 & 81,780 & 53 & 50 \\
\hline Gujarat & $1,56,753$ & $1,88,104$ & 83,322 & 75,082 & 53 & 40 \\
\hline Total & $12,47,820$ & $14,97,384$ & $8,89,528 *$ & $7,56,391 *$ & 71 & 51 \\
\hline
\end{tabular}

(* Total includes figures for Daman and Diu)

There are lots of people in the adjacent coastal transects and interior regions who find employment in fishing related fields, as the share of inhabitants of fishing villages to total secondary employment in marine fisheries ranges from 17 to 94 percent. It was found that Tamilnadu employs maximum people in the primary and secondary sector in marine fisheries. The estimated primary and secondary employment in marine fisheries does not incorporate the employment in Andaman \& Nicobar Islands, Lakshadweep, and Daman and Diu. Hence, the actual employment in marine fisheries is likely to be more than the current estimate. 


\section{Occupational profile of coastal fisherfolk in maritime states in India}

\section{Workers Population Ratio in coastal fishing villages}

The Workers Population Ratio (WPR) connotes employability of workers as ratio to total population (Table 6). The WPR of adult population in marine fisheries sector shows that 75.39 percent of the adult population is employed. In Orissa, workers exceed the adult population and WPR of total population was 64.21. The lowest WPR to adult population was seen in Daman and Diu (UT) and Kerala. In Kerala, the low WPR may be due to lower participation of women in fisheries sector. It is found that most of the women in fisheries sector in Kerala are confined to secondary sector on peeling and fish vending activities. Highest labour participation was seen in Orissa followed by Andhra Pradesh.

Table 6. Labour participation of coastal fishing population in marine fisheries (2005)

\begin{tabular}{lrcc}
\hline State & Total employed & $\begin{array}{c}\text { WPR } \\
\text { (adult population) }\end{array}$ & $\begin{array}{c}\text { WPR } \\
\text { (total population) }\end{array}$ \\
\hline West Bengal & 130,459 & 79.80 & 48.40 \\
Orissa & 289,175 & 106.73 & 64.21 \\
Andhra Pradesh & 300,233 & 99.00 & 58.87 \\
Tamil Nadu & 324,234 & 60.22 & 41.02 \\
Pondichery & 22,133 & 75.19 & 51.44 \\
Kerala & 224,606 & 52.59 & 37.30 \\
Karnataka & 90,831 & 73.67 & 53.14 \\
Goa & 6,399 & 81.89 & 59.98 \\
Maharashtra & 164,579 & 74.47 & 51.53 \\
Gujarat & 168,794 & 88.44 & 52.22 \\
Daman and Diu & 7,549 & 42.38 & 25.76 \\
Total & $1,728,992$ & 75.39 & 49.13
\end{tabular}

The overall dependency ratio of marine fisherfolk in India is estimated to be 2.04 denoting that every person working in marine fisheries sector supports two persons. It varies across the states from 1.56 (Orissa) to 3.88 (Daman and Diu). Among those employed in marine fisheries, most of them are active fishermen while 43.75 percent are in secondary sector occupations and 4.80 percent are involved in other activities including tertiary sector (Table 7). However, majority of those employed in marine fisheries are in secondary sector in the states of Orissa, Andhra Pradesh on the East Coast and Karnataka, Goa, Maharashtra, and Gujarat on the West coast. Coupled with the intensity of marine fishing more people are involved in active fishing in 
Tamil Nadu, Kerala, Andhra Pradesh, and Orissa. The quality concerns after the WTO, wide spread consumer preference and increased price for value added products in the international markets have increased the scope of secondary sector in fisheries. These developments have led to improvement in handling and processing facilities adjacent to export units adding to the employability. The fisherfolk employment in other sectors ranged from 1.03 (Daman and Diu) to 8.26 percent (Karnataka) in different states.

Table 7. State wise occupational pattern of coastal fisherfolk in India (2005).

\begin{tabular}{|c|c|c|c|c|}
\hline \multirow[b]{2}{*}{ State } & \multicolumn{4}{|c|}{ Number of fisherfolk engaged in } \\
\hline & Primary Sector & $\begin{array}{c}\text { Secondary } \\
\text { sectors }\end{array}$ & $\begin{array}{l}\text { Other } \\
\text { sector }\end{array}$ & Total \\
\hline West Bengal & $\begin{array}{l}70,750 \\
(54.23)\end{array}$ & $\begin{array}{l}57741 \\
(44.26)\end{array}$ & $\begin{array}{l}1,968 \\
(1.51)\end{array}$ & $\begin{array}{l}130,459 \\
(100)\end{array}$ \\
\hline Orissa & $\begin{array}{l}121,282 \\
(41.94)\end{array}$ & $\begin{array}{l}152,534 \\
(52.75)\end{array}$ & $\begin{array}{l}15,359 \\
(5.31)\end{array}$ & $\begin{array}{l}289,175 \\
(100)\end{array}$ \\
\hline Andhra Pradesh & $\begin{array}{l}138,614 \\
(46.17)\end{array}$ & $\begin{array}{l}152,892 \\
(50.92)\end{array}$ & $\begin{array}{l}8,727 \\
(2.91)\end{array}$ & $\begin{array}{l}300,233 \\
(100)\end{array}$ \\
\hline Tamil Nadu & $\begin{array}{l}206,908 \\
(63.81)\end{array}$ & $\begin{array}{l}104,509 \\
(32.23)\end{array}$ & $\begin{array}{l}12,817 \\
(3.95)\end{array}$ & $\begin{array}{l}324,234 \\
(100)\end{array}$ \\
\hline Pondichery & $\begin{array}{l}10,341 \\
(46.72)\end{array}$ & $\begin{array}{l}10,095 \\
(45.61)\end{array}$ & $\begin{array}{l}1697 \\
(7.67)\end{array}$ & $\begin{array}{l}22,133 \\
(100)\end{array}$ \\
\hline Kerala & $\begin{array}{l}140,222 \\
(62.43)\end{array}$ & $\begin{array}{l}71,074 \\
(31.64)\end{array}$ & $\begin{array}{l}13,310 \\
(5.93)\end{array}$ & $\begin{array}{l}224,606 \\
(100)\end{array}$ \\
\hline Karnataka & $\begin{array}{l}37,632 \\
(41.43)\end{array}$ & $\begin{array}{l}45,699 \\
(50.31)\end{array}$ & $\begin{array}{l}7,500 \\
(8.26)\end{array}$ & $\begin{array}{l}90,831 \\
(100)\end{array}$ \\
\hline Goa & $\begin{array}{l}2,515 \\
(39.30)\end{array}$ & $\begin{array}{l}3,382 \\
(52.85)\end{array}$ & $\begin{array}{l}502 \\
(7.84)\end{array}$ & $\begin{array}{l}6,399 \\
(100)\end{array}$ \\
\hline Maharashtra & $\begin{array}{l}72,074 \\
(43.79)\end{array}$ & $\begin{array}{l}81,780 \\
(49.69)\end{array}$ & $\begin{array}{l}10725 \\
(6.52)\end{array}$ & $\begin{array}{l}164,579 \\
(100)\end{array}$ \\
\hline Gujarat & $\begin{array}{l}83,322 \\
(49.36)\end{array}$ & $\begin{array}{l}75,082 \\
(44.48)\end{array}$ & $\begin{array}{l}10,390 \\
(6.16)\end{array}$ & $\begin{array}{l}168,794 \\
(100)\end{array}$ \\
\hline Daman and Diu & $\begin{array}{l}5,868 \\
(77.73)\end{array}$ & $\begin{array}{l}1,603 \\
(21.23)\end{array}$ & $\begin{array}{l}78 \\
(1.03)\end{array}$ & $\begin{array}{l}7,549 \\
(100)\end{array}$ \\
\hline Total & $\begin{array}{l}889,528 \\
(51.45)\end{array}$ & $\begin{array}{l}756,391 \\
(43.75)\end{array}$ & $\begin{array}{l}83,073 \\
(4.80)\end{array}$ & $\begin{array}{l}1,728,992 \\
(100)\end{array}$ \\
\hline
\end{tabular}

* Figures in parenthesis denote percentage to total 


\section{Labour involvement in secondary sector}

The state wise break up of the secondary sector activities in marine fisheries is given in Table 8. In West Bengal, Andhra Pradesh, and Gujarat majority employed in secondary sector are engaged as contract labourers at landing centres to retail points. The major occupation of fisherfolk engaged in secondary sector is marketing of fish in Maharashtra (53.59 percent), Goa (49.91 percent), Tamil Nadu (34.57 percent) and UT's Pondichery (63.33 percent) and Daman and Diu (54.90 percent). Both marketing of fish and contract labourers are predominant in Orissa (20.78 percent, 24.77 percent), Kerala (25.29 percent, 24.26 percent) and Karnataka (31.35 percent, 30.73 percent). In Orissa, Andhra Pradesh, and Maharashtra, curing/processing was taken up by significant portion of workforce within the secondary sector. In Kerala peeling work was predominantly undertaken in the secondary sector, mostly by women, due to the existence of more number of export units.

Table 8. State wise employment pattern in secondary sector in coastal villages (2005)

\begin{tabular}{|c|c|c|c|c|c|c|c|}
\hline State & $\begin{array}{l}\text { Marketing } \\
\text { of fish }\end{array}$ & $\begin{array}{l}\text { Making/rep } \\
\text { airing net }\end{array}$ & $\begin{array}{l}\text { Curing/ } \\
\text { Processing }\end{array}$ & Peeling & Labourers & Others & Total \\
\hline West Bengal & $\begin{array}{l}5237 \\
(9.07)\end{array}$ & $\begin{array}{c}15326 \\
(26.54)\end{array}$ & $\begin{array}{l}4705 \\
(8.15)\end{array}$ & $\begin{array}{c}478 \\
(0.83)\end{array}$ & $\begin{array}{c}26151 \\
(45.29)\end{array}$ & $\begin{array}{c}5844 \\
(10.12)\end{array}$ & $\begin{array}{l}57741 \\
(100)\end{array}$ \\
\hline Orissa & $\begin{array}{c}31691 \\
(20.78)\end{array}$ & $\begin{array}{c}40252 \\
(26.39)\end{array}$ & $\begin{array}{c}27849 \\
(18.26)\end{array}$ & $\begin{array}{l}3167 \\
(2.08)\end{array}$ & $\begin{array}{c}37781 \\
(24.77)\end{array}$ & $\begin{array}{l}11794 \\
(7.73)\end{array}$ & $\begin{array}{c}152534 \\
(100)\end{array}$ \\
\hline Andhra Pradesh & $\begin{array}{c}34337 \\
(22.46)\end{array}$ & $\begin{array}{c}23926 \\
(15.65)\end{array}$ & $\begin{array}{c}28319 \\
(18.52)\end{array}$ & $\begin{array}{c}2996 \\
(1.96)\end{array}$ & $\begin{array}{c}55372 \\
(36.22)\end{array}$ & $\begin{array}{c}7942 \\
(5.19)\end{array}$ & $\begin{array}{c}152892 \\
(100)\end{array}$ \\
\hline Tamil Nadu & $\begin{array}{c}36126 \\
(34.57)\end{array}$ & $\begin{array}{c}19051 \\
(18.23)\end{array}$ & $\begin{array}{c}6250 \\
(5.98)\end{array}$ & $\begin{array}{l}2107 \\
(2.02)\end{array}$ & $\begin{array}{c}25657 \\
(24.55)\end{array}$ & $\begin{array}{c}15318 \\
(14.66)\end{array}$ & $\begin{array}{c}104509 \\
(100)\end{array}$ \\
\hline Pondichery & $\begin{array}{c}6393 \\
(63.33)\end{array}$ & $\begin{array}{c}630 \\
(6.24)\end{array}$ & $\begin{array}{c}364 \\
(3.61)\end{array}$ & $\begin{array}{c}5 \\
(0.05)\end{array}$ & $\begin{array}{c}714 \\
(7.07)\end{array}$ & $\begin{array}{c}1989 \\
(19.70)\end{array}$ & $\begin{array}{l}10095 \\
(100)\end{array}$ \\
\hline Kerala & $\begin{array}{c}17976 \\
(25.29)\end{array}$ & $\begin{array}{c}9560 \\
(13.45)\end{array}$ & $\begin{array}{c}3881 \\
(5.46)\end{array}$ & $\begin{array}{c}8057 \\
(11.34)\end{array}$ & $\begin{array}{c}17242 \\
(24.26)\end{array}$ & $\begin{array}{c}14358 \\
(20.20)\end{array}$ & $\begin{array}{l}71074 \\
(100)\end{array}$ \\
\hline Karnataka & $\begin{array}{c}14327 \\
(31.35)\end{array}$ & $\begin{array}{c}7876 \\
(17.23)\end{array}$ & $\begin{array}{c}3342 \\
(7.31)\end{array}$ & $\begin{array}{c}581 \\
(1.27)\end{array}$ & $\begin{array}{c}14043 \\
(30.73)\end{array}$ & $\begin{array}{c}5530 \\
(12.10)\end{array}$ & $\begin{array}{l}45699 \\
(100)\end{array}$ \\
\hline Goa & $\begin{array}{c}1688 \\
(49.91)\end{array}$ & $\begin{array}{c}479 \\
(14.16)\end{array}$ & 0 & 0 & $\begin{array}{c}515 \\
(15.23)\end{array}$ & $\begin{array}{c}700 \\
(20.70)\end{array}$ & $\begin{array}{l}3382 \\
(100)\end{array}$ \\
\hline Maharashtra & $\begin{array}{l}43822 \\
(53.59)\end{array}$ & $\begin{array}{c}9086 \\
(11.11)\end{array}$ & $\begin{array}{c}9209 \\
(11.26)\end{array}$ & $\begin{array}{c}1439 \\
(1.76)\end{array}$ & $\begin{array}{c}11565 \\
(14.14)\end{array}$ & $\begin{array}{c}6659 \\
(8.14)\end{array}$ & $\begin{array}{l}81780 \\
(100)\end{array}$ \\
\hline Gujarat & $\begin{array}{c}14885 \\
(19.82)\end{array}$ & $\begin{array}{c}13452 \\
(17.92)\end{array}$ & $\begin{array}{c}3212 \\
(4.28)\end{array}$ & $\begin{array}{l}4310 \\
(5.74)\end{array}$ & $\begin{array}{c}31366 \\
(41.78)\end{array}$ & $\begin{array}{c}7857 \\
(10.46)\end{array}$ & $\begin{array}{l}75082 \\
(100)\end{array}$ \\
\hline Daman and Diu & $\begin{array}{c}880 \\
(54.90)\end{array}$ & $\begin{array}{c}80 \\
(4.99)\end{array}$ & $\begin{array}{c}11 \\
(0.69)\end{array}$ & $\begin{array}{c}3 \\
(0.19)\end{array}$ & $\begin{array}{c}256 \\
(15.97)\end{array}$ & $\begin{array}{c}373 \\
(23.27)\end{array}$ & $\begin{array}{l}1603 \\
(100)\end{array}$ \\
\hline Total & $\begin{array}{l}207362 \\
(27.41)\end{array}$ & $\begin{array}{l}139718 \\
(18.47)\end{array}$ & $\begin{array}{c}87142 \\
(11.52)\end{array}$ & $\begin{array}{l}23143 \\
(3.06)\end{array}$ & $\begin{array}{l}220662 \\
(29.17)\end{array}$ & $\begin{array}{c}78364 \\
(10.36)\end{array}$ & $\begin{array}{c}756391 \\
(100)\end{array}$ \\
\hline
\end{tabular}

* Figures in parenthesis denotes percentage to total 


\section{Women in marine fisheries: A cross section of secondary sector employment}

The activity wise occupational structure of fisherfolk engaged in secondary sector is given in Table 9. Fish marketing and labourers for various activities from the landing centre to retail points provide employment to more than 56 percent of the fisherfolk engaged in secondary sector. While marketing is dominated by females (MF ratio (Male Female ratio) of 2.8), labour in the secondary sector is done by men (MF ratio of 0.4 ). Curing /processing and peeling are undertaken by women (MF ratio of 3.1 and 3.4, respectively). Male female participation in secondary sector is almost equal denoted by the ratio of 0.9 . Of the fisher population engaged in secondary sector, women accounted for 48 percent of the work force in marketing, curing/processing and peeling sectors.

Table 9. Gender wise occupational structure in secondary sector (2005)

\begin{tabular}{|c|c|c|c|c|c|}
\hline \multirow[b]{2}{*}{$\begin{array}{l}\text { Sl. } \\
\text { No }\end{array}$} & \multirow[b]{2}{*}{$\begin{array}{l}\text { Activity in secondary } \\
\text { sector }\end{array}$} & \multicolumn{3}{|c|}{ Number of fisherfolk involved } & \multirow{2}{*}{$\begin{array}{l}\text { Male female } \\
\text { participation } \\
\quad \text { Ratio }\end{array}$} \\
\hline & & Male & Female & Total & \\
\hline 1 & Marketing & $\begin{array}{l}54670 \\
(26.36)\end{array}$ & $\begin{array}{l}152692 \\
(73.64)\end{array}$ & $\begin{array}{l}207362 \\
(100)\end{array}$ & 2.8 \\
\hline 2 & Making/repairing of net & $\begin{array}{l}111661 \\
(79.92)\end{array}$ & $\begin{array}{l}28057 \\
(20.08)\end{array}$ & $\begin{array}{l}13971 \\
8(100)\end{array}$ & 0.3 \\
\hline 3 & Curing/processing & $\begin{array}{l}21211 \\
(24.34)\end{array}$ & $\begin{array}{l}65931 \\
(75.66)\end{array}$ & $\begin{array}{l}87142 \\
(100)\end{array}$ & 3.1 \\
\hline 4 & Peeling & $\begin{array}{l}5251 \\
(22.69)\end{array}$ & $\begin{array}{l}78921 \\
(77.31)\end{array}$ & $\begin{array}{l}23143 \\
(100)\end{array}$ & 3.4 \\
\hline 5 & Labourer & $\begin{array}{l}153431 \\
(69.53)\end{array}$ & $\begin{array}{l}67231 \\
(30.47)\end{array}$ & $\begin{array}{l}220662 \\
(100)\end{array}$ & 0.4 \\
\hline 6 & Others & $\begin{array}{l}44704 \\
(57.05)\end{array}$ & $\begin{array}{l}33660 \\
(42.95)\end{array}$ & $\begin{array}{l}78364 \\
(100)\end{array}$ & 0.8 \\
\hline & Total & $\begin{array}{l}390928 \\
(51.68)\end{array}$ & $\begin{array}{l}365463 \\
(48.32)\end{array}$ & $\begin{array}{l}756391 \\
(100)\end{array}$ & 0.9 \\
\hline
\end{tabular}

* Figures in parenthesis denote percentage to total

\section{Labour migration - Case of Tamil fisherfolk of Kanyakumari coast}

The term migration is presented as a delimitated theme among spatial mobility, which is defined in congruence with the changes in the geographical location occupations of the respondent (Richard, 1969). The tendency of moving from place to place or from one occupation to another may be due to various reasons viz., geographic, demographic, and ethnographic; differences in skills, knowledge, and abilities; demand and supply conditions of resources; socio-economic characteristics; political and religious forces; 
employment potential and market orientation. These tendencies, unevenly distributed within and among places, create inequalities with the community and results in a series of interlinked economic and social consequences.

The growth pattern in favour of mechanised and motorised sectors along with increased capital investments in these sectors have absorbed a major chunk of active fishermen, thus resulting in large-scale disguised unemployment within the sectors. Ultimately, this has resulted in the emergence of spatially mobile fishermen groups, which could be termed as migrant fisher folk. They may be either temporary or permanent settlers. One example of such migrant fisher folk who are fishing off the Kerala coast is fishermen of Tamil Nadu. Most of the migrants hail from the fishing villages of Thoothoor, Neerodi, Marthandamthurai, Vallavilai, Eraviputhenthurai, Chinnathurai, Thoothoor, Colachel, Poothurai, and Eraiyumanthurai. These fishers go for multi-day fishing throughout the year and anchor at any of the landing centres or harbours off the Kerala coast. The migratory pattern of shark fishers in Thoothoor, Vallavilai, and Colachel regions in Tamil Nadu showed that 35 percent were non migrants (local fishing) and 65 percent were migrants (in-country and foreign). Among the in-country migrant shark fishers, 85 percent relocate to coasts of Kerala (Cochin, Vizhinjam, Kollam, Kozhikode, Kannur, and Kasargode), Karnataka (Mangalore, Malpe and Gangoli), Goa, Maharashtra, and Gujarat. Foreign migration constituted 15 percent of total migratory fishers and they go for fishing along the coasts of Qatar, Saudi Arabia, Dubai, and Doha. The nonmigratory units had average investment in fishing units ranging from Rs. 4000 for nonmechanised to Rs. 13.5 lakh for mechanised units. Technological advancement has facilitated fish finding devices like ecosounder and GPS and communication technologies to facilitate market intelligence. The capital investment in migratory units has increased considerably due to increase in size of vessel with storage capacity and use of electronic gadgets and telecommunication devises. For the migratory units (Multi-day mechanised fishing units), average investment varies from Rs. 15 lakh to Rs. 30 lakh.

There are several problems faced by these migrant fisherfolk that need to be addressed. The study focuses on the constraints of different stakeholders in the migratory pattern, including in-country migrants, foreign migrants, families of migrants and marine fisheries sector as a whole.

\section{Demographic profile of "shark fishers"}

Local fisherfolk encounter many problems that induce migration. Major lacunae are insufficient landing and berthing facilities, inability to realise competitive prices in the local market due to lack of common landing points, rivalry and frequent conflicts among villages in resource sharing, restrictions in fishing, vulnerability, and debt trap 
of local money lenders and traders. High demand for shark in international market and its earning potential induces the fishermen to migrate according to availability of fish stocks. Accessibility to landing points and berthing facilities in other states/countries is another factor responsible for migration.

Among the respondents, 62 percent are literate with 95 percent of them having education till the primary level and 5 percent till secondary level. Various studies reveal that migration has helped the migrant households avoid hunger, starvation, and death and it (migration) became a vital livelihood strategy, though it failed to evaluate the economic status of all migrating households (Sundari 2005; Vijay 2002; Standing 1985). The housing pattern of the migrant fisherfolk is better than the nonmigrants. While most of the non-migratory fishers lived in kutcha houses of 125 to 300 sq.ft, in-country migrants lived in tiled/concrete houses of 500-700 sq.ft. The most affluent category is the foreign migrants who built 850-1200 sq.ft concrete houses.

\section{Constraints of in-country migrants}

The prospects of migration are attracting more and more people, but there are inherent problems associated with foreign and in-country migration. The common problems encountered by the shark fishermen of Thoothoor were identified in the study

- 86 percent of respondents opined that seasonal nature of fisheries does not ensure moderate/high returns. Though good returns are reaped in some of the seasons, there are lean seasons also in which catch is very low that they are forced to borrow. Informal borrowing results in debt trap for 79 percent of the respondents, channelising the revenue from bumper harvests to settlement of debtors. They are often forced to borrow for next journey repeating this cycle

- Frequent clashes with locals of the landing centers in other states was experienced by 44 percent of respondents

- Exploitation was fleet by 38 percent of migrant fishers due to ignorance of language and other factors

- 63 percent of them said that there was collection of high rent for lodging and price discrimination in purchasing fishing requisites and other essentials in the other states

- 43 percent of respondents admitted that traders advance money before voyage and they are bound to forced sales at lower prices

- Unnecessary delay in payment of sale proceeds by the merchants was experienced by 43 percent 
- Reports of missing of fishing boats/fishermen occurred frequently in migratory fishing and 33 percent of respondents said that there is lack of Government initiatives in tracing them

- Ergonomic problems due to long fishing trips without adequate facilities was experienced by 72 percent of them

- 69 percent of them said that quality of fish is usually affected because of lengthy voyages and absence of proper storage facilities

\section{Constraints of families of migrant fishers}

Continuous absence of fishermen from their families increases the burden of housewives in looking after the families and caring of children. Irregular inflow of remittances to households affects the socio-economic milieu of the families. Most often, families borrow for day to day expenses as fishermen return only by a month or more as experienced by 65 percent of respondents. Women counterparts had to mobilize working capital for next round of fishing when male members are away in case of 58 percent of respondents. 71 percent of respondents said that debtors pose frequent enquires and force families for repayment in absence of male members. Occasional missing or nontraceability creates tension in families ( 37 percent). 82 percent of fishermen returning after voyage have to prepare for next voyage and have no time for family matters. Irregular income forces female counterparts to take up alternative avocations in case of 58 percent of respondents.

\section{Perils of foreign migrants}

Though the earning potential of foreign migration is higher, there are more severe problems associated with it. Fish workers are often treated as slaves by sponsors, boat owners, and public. Exploitation due to illiteracy is also rampant. While sharing is existent in the foreign vessels also, the fishers rarely know the actual price of fish sold in the market. Lack of facilities in fishing units affects the quantum of catch. Detention by neighbouring countries while fishing due to crossing of maritime borders is common in overseas fishing due to ignorance. Agreements are not honoured by sponsors/boat owners and passports and other documents are frequently impounded. In addition, if the fishers face any threat from the sponsors, there is no accessibility to the Indian High Commission/Embassy to address their problems.

\section{Consequences of migration}

The adverse consequences of migration in marine fisheries sector include capital deepening of fishing crafts. The motorization of boats has increased the economic burden 
of the traditional fishing units; consequently polarization of fishermen into owners and workers has taken place; also fishing efforts get concentrated in selected regions. Due to increased mechanization and with the introduction of nylon nets in the place of handmade nets, women have lost their major source of living which has forced them to shift to non-fishing avocations for alternative income earning.

Labour in the traditional sector moves towards modern fishing technologies; the movement resulting in a situation in which the traditional fishing sector gets integrated into the global economy and labour loses its traditional skills. Reorganization and work and division of labour have resulted in the disappearance of the traditional sharing system and the emergence of an inequitable distribution of incomes among participants in the fishing activity.

\section{Conclusion}

The economic development in the coastal belt is not in congruence with the other regions and the socio economic status remains backward compared to other sectors. The fishing population has grown over the years; inducing more and more people in primary, secondary, and tertiary sectors. Disguised unemployment is rampant with the increased earning potential due to introduction of labour saving and capital intensive mechanised fishing units. The non-mechanized sector is slowly being phased out, driving the labourers to other sectors, leading to overcrowding and resultant low per capita earnings. It was estimated that a total of 29.44 lakh people are employed in marine fisheries sector of which about 12.5 lakh people are involved in active fishing, 15 lakh in secondary sector and 2 lakh in tertiary sector. Out of those employed in marine fisheries sector, the coastal fisherfolk accounts for 71 percent in primary sector, 50 percent in secondary sector and 42 percent in tertiary sector. The case study of migratory fisherfolk highlights their common problems and their families. The high earning potential of shark in domestic and international markets induce the fishers for migratory fishing in search of fishing grounds. However, fisherfolk encounter several problems during the long duration trips away from their homes, creating social tension for families and poor ergonomics for themselves without realizing much out of the trip due to debt bondage. The families, especially the women households have to run the families with seasonal income from male members after trips that are often trapped with non-formal sources of debt. There are frequent conflicts among the migrants and local fisherfolk. It requires high priority to evolve strategies to protect the rights of migratory fisherfolk both incountry and foreign. In addition, fisheries infrastructure in their native places also should be developed. Concrete and comprehensive long term policies for ocean development in terms of resource exploitation, conservation and regulation, domestic and export 
marketing, aquaculture and mariculture, human resource utilization and management are to be evolved and implemented in a phased manner for the balanced and sustainable development of marine fishery sector in our country. It is required to frame policies to suit the changing fishing methods and evolve programmes for capacity building of fisherfolk and their families associated with migratory fishing.

\section{Acknowledgement}

We express our heartfelt thanks to Dr. Mohan Joseph Modayil, Director, CMFRI for the constant encouragement in the preparation of this paper. Thanks are also due to all Technical Staff who have contributed in the collection of data.

\section{References}

Richard, Hall H. 1969. Occupations and the Social Structure. Prentice Hall, Elglewood eliffs, New Jersey. Sathiadhas, R., R. Reghu and Sheela Immanuel. 1997. Human resource utilisation, productivity and earnings in Indian marine fisheries. Sea Food Export Journal. XXX(4): 51-55.

Standing Guy .1985. Labour Circulation and Labour Process. ILO, Geneva.

Sundari, M .2005. Migration as a Livelihood Strategy: A Gender Perspective. Economic and Political Weekly:XL (22 \& 23): 2295-2303.

Vijay G .2002. New Industrial Labour: Insecure Employment, Social Conflict and Labour Rights. In: Structural Adjustment and its Implications for Human Rights (eds. G.Saibaba and Srinivas Rao), Serial Publication. New Delhi. 